PROBLEMS

OF EDUCATION

IN THE $21^{\text {st }}$ CENTURY

Vol. 75, No. 3, 2017

\section{WHAT IS A GOOD PRACTICE OF SCIENCE TEACHING? SOME PATHS}

Mónica Baptista

University of Lisbon, Portugal

E-mail: mbaptista@ie.ulisboa.pt

\begin{abstract}
Physics classes were different this year. The teacher has prepared different activities that interested us, and enabled us to understand what we were doing and their purposes; activities were undertaken by us and we really learned ... These were very good lessons and I achieved a great mark (Maria, 17 years old, $9^{\text {th }}$ grade).
\end{abstract}

Maria is a 17 year old $9^{\text {th }}$ grade student with low academic success. Her school history is marked by several stories of failure in Physics and Chemistry. Yet, the $9^{\text {th }}$ grade of Maria was different; as she says, she managed to achieve "a great mark". Therefore, what has taken Maria to find the Physics classes so good? The answer to this question leads us to another one, more complex, that can have various possible answers: After all, what is a good practice of science teaching?

To answer this question requires, first of all, to think about what students are expected to learn and what competencies they should obtain in school to meet the challenges of today's society, in all its uncertainty and endless changes. Nowadays, it is widely acknowledged that to understand and act in an informed and reflected manner in such a society it is essential that students develop their critical thinking and creativity as well as problem solving, communication, digital, social, intercultural and linguistic skills.

And, how can science teachers help their students to develop those competencies? From a competency development perspective, it is not enough to get students to understand scientific concepts, theories and facts. It will also be essential to create learning situations that favor the development of competencies. So, it is crucial that such situations can be appealing, and relevant to the students, by making sense to them, and involving them in their own learning. This was one of the aspects that Maria's teacher took into account when she mentioned, "[teacher's proposals] enabled us to understand what we were doing and their purposes; activities were undertaken by us and we really learned".

Then, what has Maria's teacher done differently? She developed inquiry activities. Inquiry has been pointed out in literature as a teaching approach that teachers can use in their classrooms. It allows students to search the way forward to find one or more solutions to a problem through multifaceted tasks: observation, hypothesis formulation, search in various sources of information, planning a research, reviewing what we already know about the experience, using tools to analyze and interpret data, communicate results. An essential aspect of inquiry is that students are encouraged to prioritize evidence to answer questions, to use evidence to develop explanations, by linking them to scientific knowledge. These characteristics place students at the center of their learning, promote the understanding of everyday phenomena, support argumentation and decision-making, as well as reasoning and critical thinking. Given these potentialities, inquiry is one of the dimensions about what can appropriately be called a good practice of science teaching. However, the implementation of inquiry in classrooms presents a number of significant challenges for teachers. 
Therefore, what sort of strategies can facilitate the active involvement in inquiry implementation? An appropriate one is to involve teachers in the development of materials, in its implementation and in the evaluation of its effect on students' learning, through the collection of data, in order to support their reflection and questioning. Research on the teaching practice itself can enhance the opportunity, supported and sustained, to reflect on the practice and look at alternatives. Researching their own practices, by means of collecting data and reflecting on it, by mobilizing theoretical ideas, can help bridging the gap between theory and practice. So, it is a powerful means for teachers learning about their students and about the impact of the teaching processes in learning. Furthermore, collaboration among teachers is needed to strengthen the motivation to act and to create a broader set of experiences, skills and perspectives which allow to widen the opportunity to question and interpret. A teacher professional development program that involves these two dimensions - research and collaboration - is an added value to the successful practice of science teaching.

So, what formative processes can be followed? There are a multitude of processes. I shall give just two examples. The first one, PACIR, involves collaboration between teachers and researchers. It consists of an iterative cyclic process, organized around five stages: to plan (at this stage, teachers and researchers design a set of inquiry activities); to act (teachers implement the activities and researchers observe some classes and support the teachers); to collect (teachers collect information regarding students' learning, involvement, difficulties and ways of overcoming it; researchers support teachers in developing instruments for collecting data); to interpret (teachers and researchers interpret the results); to reflect (teachers and researchers reflect on their experiences and their classroom and curricular contexts, they explore relationships between new classroom practices and students' experiences, they revise, if needed, the lessons' plan and the inquiry activities, and they mobilize theoretical knowledge for constructing new understandings regarding teaching and learning). The second example is lesson study. Lesson study has been pointed out in literature as a model of teacher training that involves teachers in a small research carried out in their professional practice, in a collaborative and reflexive context. Lesson study has its origin in Japan (Jugyou Kenkyuu: Jugyou means lesson and kenkyuu means study), but all over the world different research has arisen, showing its potential for teachers' professional development. A key aspect of lesson study is that teachers focus on students' learning rather than in teachers work. It is a cyclical process that involves planning, research lesson, and reflection and revision phases. The planning of a research lesson starts with teachers raising a question of their interest, related to their students' learning. Then, they plan the research lesson always bearing in mind that question. During the planning phase they anticipate students' difficulties and possible answers; they build tasks and prepare instruments for observing the research lesson. The research lesson is taught by a single teacher while the others observe and take notes, paying special attention to students' learning and the strategies they use. Then, teachers meet together to reflect on what they observed and to review the lesson. The discussion of what they have observed may lead to the reformulation of the lesson plan, with some changes in the proposed tasks and in the observation instruments. The reformulated lesson may then be given again by another teacher of the group to another class.

At this juncture, this brings me back to my original question: What is a good practice of science teaching? I shall give a few paths. First, a good practice of science teaching is one that meets the interests of students and enables them to carry out their own learning in a more autonomous way. To this end, teachers have at their disposal the inquiry. Second, a good practice of science teaching is the one that integrates the research in the own practice dimension and that takes into account the importance of collaboration for the professional development of teachers. These actions are facilitated by the involvement of teachers in formative processes, such as the two professional development models presented here - PACIR and lesson study - whose 
Mónica BAPTISTA. What is a good practice of science teaching? Some paths

EDUCATIO

N THE $21^{\text {st }}$ CENTURY

Vol. 75, No. 3, 2017

214 relevance is due to the fact that both provide professional learning that meet the students' needs and the challenges they face.

Received: March 15, 2017

Accepted: June 18, 2017

Mónica Baptista

$\mathrm{PhD}$, Assistant Professor, Institute of Education, University of Lisbon, R. Branca Edmée Marques, 1649-013 Lisbon, Portugal.

E-mail: mbaptista@ie.ulisboa.pt 